\title{
Diet and Seed Dispersal by Eulemur coronatus (Gray, Primates and Lemuridae) in the Amber Mountain National Park, Madagascar
}

\author{
Kaloantsimo Sarah Chen ${ }^{1,2}$, Jun Qing $\mathrm{Li}^{1}$, Jean Rasoarahona ${ }^{2}$, Fousseni Folega ${ }^{3,4} \&$ Christophe Manjaribe $^{5}$ \\ ${ }^{1}$ College of Forestry, Beijing Forestry University, 100083, Beijing, P.R. China \\ ${ }^{2}$ Ecole Supérieure des Sciences Agronomiques, Université d'Antananarivo, BP566, Antananarivo 101, Madagascar \\ ${ }^{3}$ The Key Laboratory for Forest Resources \& Ecosystem Processes of Beijing, Beijing Forestry University, 100083, \\ P.R. China \\ ${ }^{4}$ Université de Lomé, Laboratoire de Botanique et Écologie Végétale, Faculté des Sciences, BP 1515, Lomé, Togo \\ ${ }^{5}$ Département de Biologie et Ecologie Végétales, Faculté des Sciences, Université d'Antananarivo, BP566, \\ Antananarivo 101, Madagascar \\ Correspondence: Kaloantsimo Sarah Chen, College of Forestry, Beijing Forestry University, 100083, Beijing, P.R. \\ China. E-mail: s.chen1502@yahoo.fr
}

Received: July 23, 2015 Accepted: August 17, 2015 Online Published: August 21, 2015

doi:10.5539/ijb.v7n4p20 URL: http://dx.doi.org/10.5539/ijb.v7n4p20

\begin{abstract}
Eulemur coronatus (Gray, Primates and Lemuridae) belongs to the endemic animal species in Amber Mountain National Park, Madagascar. As a frugivorous lemur, it may have an important role in the forest regeneration. However, until now, no study has carried out the role of this lemur in forest regeneration. The diet and seed dispersal by $E$. coronatus were studied to determine the potential ecological role of this lemur in regeneration of Amber forest. A group of E. coronatus was observed and monitored during 396 hours. Field observation recorded the food items taken, plant species consumed and plants organs preferred. Seeds from discarded food items left by the group of E. coronatus being followed were collected to perform the germination tests. This allowed analysis of the germination potential of the collected seeds. The results showed that feeding times for E. coronatus varied significantly $(p=0.01)$ across the study period. E. coronatus spent more time eating fruits than other organs of plants comprising $92 \%$. E. coronatus consumed 46 plant species, with plants in the family Moraceae comprising $33 \%$ of those eaten. Overall, passed seeds had significantly higher germination rates than those control seeds $(t$ $=5.53, p=0.01$ ). The average latency period of passed and control seeds ranged from 40 to 87 days and from 47.5 to 91 days, respectively. This study revealed the contribution of E. coronatus on the Amber forest regeneration and the crucial role that it can play in Madagascar forest to preserve the endemic plants species.
\end{abstract}

Keywords: Eulemur coronatus, germination test, latency period, lemur food

\section{Introduction}

The lemurs represent a unique symbol of the Madagascar's fauna community (Mittermeier et al., 2005). But, their existence is severely threatened and about $94 \%$ of lemur species are fast approaching extinction (Mittermeier et al., 2014), owing political instability, illegal lumbering, selective hunting as well as, the consequences of climate change. Eulemur coronatus (Gray, Primates and Lemuridae) is among those threatened species which has been cited in the IUCN Red List. E. coronatus is the one of small prosimian described by Gray (1842) in amber Mountain National Park, Analamera, Ankarana and Amber Forest Special Reserves. This species is a frugivore (Freed, 1996; Mittermeier et al., 2014). Despite the fact that, their habitant are placed under protection, their existence nonetheless remain threatened as result of rampant incidences of bush fires, excessive logging, overgrazing and unregulated hunting (Wilson, 1989). Loss of forest cover due to, slash-and-burn practices, charcoal production, mining exploitation and illegal logging has predisposed lemur species to harsh environmental conditions and adversely deprived them forage.

Consented efforts aimed to identifying plants species explored by lemur species as food and subsequently implementing policies to protect these plant species. It would greatly augment efforts aimed to preventing the extinction of lemurs' species and also ensure the availability of sustainable food sources. As a frugivorous primate, E. coronatus can be considered as dispersers of tropical trees, forest regeneration and enhancing ecological restoration 
as well. But we know very little about the potential role of E. coronatus in forest regeneration. The diet of E. coronatus was investigated through an observational study. The germination test was performed in order to understand the lemur's capacity for seed dispersal and potential impact on the forest regeneration. We hold strong view that, findings from this investigation will further help in updating the knowledge base regarding plant species consumed and the effect of their gut passage of seed germination. In particular, this study would be useful to wildlife managers in the park and would greatly enhance the conservation strategies in framework of Amber forest in daily management. The specific objectives were: 1) to determine the plant species composition consisting in the diet of E. coronatus from Amber forest; 2) to assess the potential of lemur on plant regeneration by the analyses of the influence of gut-passage on the germination rate and the latency length of the seeds of the dietary of E. coronatus.

\section{Materials and Methods}

\subsection{Animal Description}

The crowned lemur (Eulemur coronatus Gray, 1842) is a small-size lemur with a body measuring $31-36 \mathrm{~cm}$ long plus a $42-51-\mathrm{cm}$ long tail and weighing 1.1-1.3 kg (Terranova \& Coffman, 1997). E. coronatus is sexually dichromatic (Mittermeier et al., 2014). This species is endemic of the northern tip of Madagascar. They live sympatrically with $E$. sanfordi (Freed, 1996; Mittermeier et al., 2014).

\subsection{Study Area}

The study was conducted at complex of Amber Mountain National Park (Figure 1), located between $12^{\circ} 33^{\prime}-$ $12^{\circ} 44^{\prime} \mathrm{S}$ and $49^{\circ} 03^{\prime}-49^{\circ} 13^{\prime} \mathrm{E}$. A complex of protected areas covers 23,010 ha of the Antsiranana II District, which is an administrative subdivision of one of 22 regions of Madagascar delineated in 2004, the Diana Region. The elevation of the study site varies from 850 to $1475 \mathrm{~m}$ with a slope up to $30^{\circ}$. The annual air temperature ranges from $17.60{ }^{\circ} \mathrm{C}$ to $21{ }^{\circ} \mathrm{C}$ (Rossi \& Rossi, 1998; Trigui, 2010). The dry season starts from May to November and the rainy season runs from December to April. The park receives abundant rainfall throughout the year regardless of the season. However, the mean annual rainfall is about $2978 \mathrm{~mm}$ (Humbert \& Cours Darne, 1965; Angap, 1998).

The major floristic features of Amber Mountain National Park consist of the mountain rainforest, forest herbaceous undergrowth and evergreen seasonal forest. The complex flora consists of many tree species such as Dalbergia sp., Canarium madagascariensis, Terminalia mantaly, Neodypsis sp., Aeranthes sp. (Asparagales and Orchidaceae) introduced species such as Abies sp., Eucalyptus sp., Araucaria sp., and Cinchona sp. (Gentianales and Rubiaceae) (Angap, 1998). Faunal studies performed on vertebrates identified 24 species of Amphibians, 49 species of Reptiles, 77 species of Birds and 19 Mammals species (Rakotoarimanana \& Edmond, 1990).

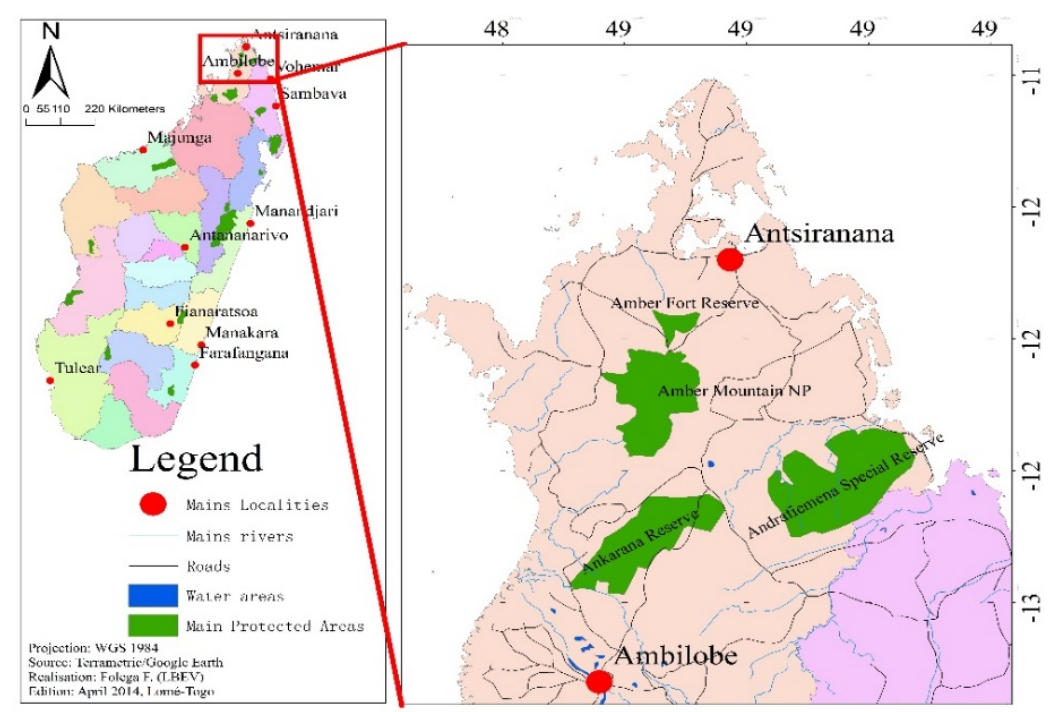

Figure 1. Study Area

\subsection{Data Collection}

One group of E. coronatus that had been habituated to human presence was chosen for study and data collection from September 2013 to February 2014. This study period corresponds to 2 seasons, the end of dry season 
(September-November) and the beginning of rainy season (December-February). The study group included 5 males and 3 females.

\subsubsection{Diet}

The data were obtained using direct observation of a single focal individual following the methods described by Stevenson (2000). The observations were made by following focal animal on 3 consecutive days per week for 6 hours per day. Different focal individuals were used to ensure representation of all group members in our sample, with an average of 44 hours of observation per individual.

The observations were recorded every 5 min based on sampling the focal individual (Altmann, 1974). Thus, 72 entries were recorded on the focal individual per day. In total, a focal animal was observed for 396 hours with that time distributed over 6 months or $72 \mathrm{~h}$ per month; however, in February observations were conducted for only 36 hours.

Each observation was classified into one of three categories of activities, resting (when the lemur is considered to be at rest), feeding (defined as the consumption of solid food items and all activities related to feeding) and moving (all remaining activities).

The time spent by the focal individual feeding on each plant species and the parts of these plant species being consumed were recorded. The plant species used by the focal lemur were recorded by their vernacular and scientific names. Food species were also flagged for later collection including for making herbarium specimens.

Each plant part eaten by the focal individual was identified and classified as leaves (young or mature), flowers, fruits (unripe, ripe) and others.

\subsubsection{Seed and Germination Test}

During the feeding observations of the focal animal, all fresh faecal samples that fell to the ground from all individuals in the group were collected (Stevenson, 2000; Poulsen et al., 2001). In total, 129 fresh faecal samples from one group of $E$. coronatus were recorded. The defecated seeds were extracted from faecal sample by filtering faeces through a $1 \mathrm{~mm}$ mesh sieve following the methods of Stevenson (2000) and stored in plastic bags prior to identification. Seeds identification was confirmed by comparing these seeds with those of mature trees in the field study. The defecated or passed seeds were counted and measured using calipers. Seed were classified into three size categories according to Traveset and Verdu (2002): large $>10 \mathrm{~mm}$, medium 5-10 mm and small $<5-\mathrm{mm}-$ diameter. Passed seeds were classified in two categories: damaged and intact. Passed seeds are considered damaged if they had visible injuries including bite marks, others scars, or seed damage; all other seeds were categorized as intact following the methods of Razafindratsima and Martinez (2012).

Germination tests were performed using intact large-sized defecated seeds; these were chosen because of the low numbers of small- and medium-sized seeds collected from faeces. The control or non-passed seeds were extracted from ripe fruits collected under fruiting trees using nets or on the ground throughout the study site. Intact passed seeds and control seeds were planted in a nursery at the Amber forest. The following methods were used by the conservation agent in the area; the nursery consisted of four $4.90-\mathrm{m}^{2}$ seed beds. A sunshade composed of leaves was placed at $1 \mathrm{~m}$ above the ground in each seed bed to imitate the closed canopy of the forest. The soil used in the nursery was composed of forest soil to imitate the natural local conditions. We collected soil in several areas within the forest, and mixed all soils before use in the nursery. Seeds were planted in forest soil for the germination trials, and covered with 0.5 to $1 \mathrm{~cm}$ of soil. An equal number of seeds was planted for each plant species per treatment $(n=20)$. In the nursery, 280 seeds (defecated and non-passed) were planted. Germination of seed was defined as the moment the radicle appears (Stevenson et al., 2002). The time between sowing and germination was defined as the latency period. The number of germinated seeds was recorded daily.

\subsection{Data Analysis}

The time the focus lemur spent feeding on different food items in a day were estimated using the formula of Gupta and Kumar (1994):

$$
T_{a}=\left[\left(N_{a} x 100\right) / N\right]
$$

where $T_{\mathrm{a}}$ is the percentage of time spent on activity $a, N_{a}$ is number of records with activity $a$, and $N$ is the total number of records for the day.

The mean time spent feeding on a category of food (such as leaves), a food species and the number of food plants of each species eaten per day were used to calculate the monthly mean; in addition, the monthly mean was used to calculate the seasonal mean. 
The germination rate for a seed species was obtained by the percentage of dispersed and control seeds that germinated in germination trials (Stevenson, 2000).

SPSS 18.0 (IBM, Inc., Armond, NY) was used to perform the statistical analysis. One-way ANOVA was used to compare variations in feeding time across the month, feeding time on food type and number of food plants consumed monthly and seasonally. A paired t-test was used to test for differences between the germination rate of passed and non-passed seeds. For each species, Pearson's chi square test was used to analyse the germination rate to be able to assess the influence of lemur gut passage. A Mann-Whitney test was used to compare the latency period between gut-passed and non-passed seeds (for each species and between them).

\section{Results}

\subsection{Feeding Time and Food Items}

During the study period, the lemur group spent $33 \%$ of their time resting, $35 \%$ moving and $32 \%$ feeding.

The monthly percentage of time spent feeding ranged from $25 \%$ to $40 \%$ across all months. The minimum and maximum percentages of time spent feeding were in December and September, respectively (Figure 2). The feeding time varied significantly across the months $(F=5.02, p=0.01)$ and seasons $(F=4.97, p=0.03)$.

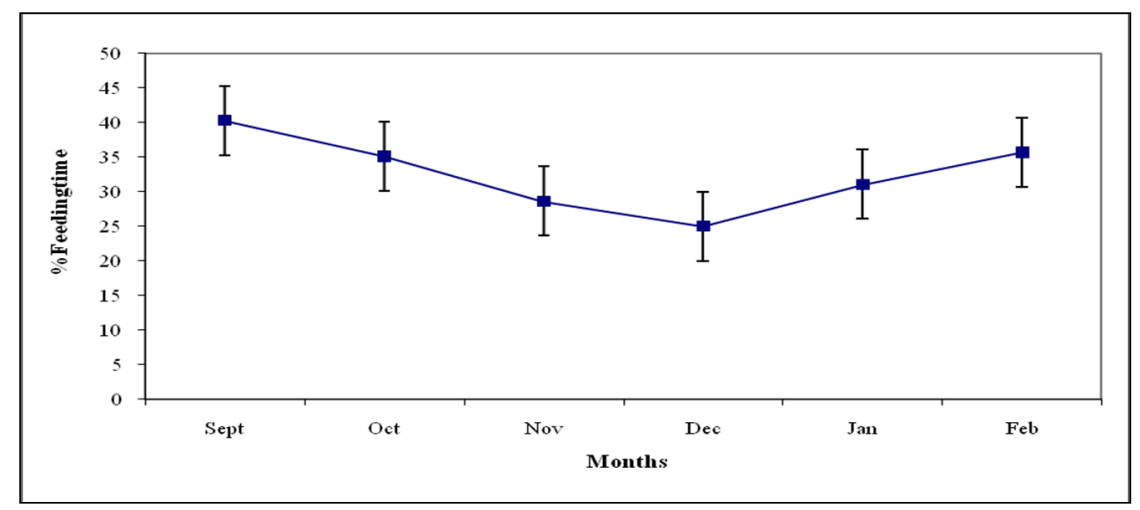

Figure 2. Monthly variation on feeding time

The daily feeding time for each food type was combined to present the overall feeding time for each food type. $E$. coronatus spent $92 \%$ of their feeding time eating fruit including ripe fruit $(58 \%)$ and unripe fruit (34\%). The time lemurs spent eating all leaves, young leaves and mature leaves was $5 \%, 3 \%$ and $2 \%$, respectively, while they spent $4 \%$ of their time eating flowers. The lemurs spent $0.1 \%$ of feeding time eating soil and another $0.1 \%$ drinking water.

The high percentage value of eaten fruit indicates that feeding on fruit is relatively more consistent in the lemur's diet. Feeding on ripe fruit was the dominant food type.

Feeding time on ripe fruit was high in all months. The amount of time lemurs spent feeding on ripe fruit varied significantly across the months $(F=5.12, p=0.01)$. The lemurs spent more than $50 \%$ of each month feeding on ripe fruit. However, they spent more than $60 \%$ of their time feeding on ripe fruit from December to February. Feeding time spent on eating ripe fruit did not vary significantly across the seasons $(F=2.06, p=0.16)$.

The feeding time on unripe fruit ranged from $7 \%$ in February to $39 \%$ in September. Feeding time on unripe fruit varied significantly across the months $(F=6.47, p=0.01)$ and seasons $(F=18.11, p=0.01)$.

The feeding time on young leaves ranged from $0.7 \%$ in February to $6 \%$ in December, and varied significantly across the months $(F=3.19, p=0.01)$ but it did not vary significantly across the seasons $(F=1.01, p=0.31)$.

The feeding time on mature leaves ranged from $0.6 \%$ in September to $4 \%$ in December, and did not vary significantly across the months $(F=1.79, p=0.13)$.

The feeding time variation on flowers varied significantly across the months $(F=6.32, p=0.01)$. Crowned lemurs fed on flowers from October to November and February with feeding time on flowers peaking at $14 \%$ in October; it also varied significantly across the seasons $(F=6.32, p=0.05)$.

Soil was consumed rarely at any time, although the lemurs are observed eating soil in September and January. Figure 3 shows the monthly variation in feeding time on different food types. 


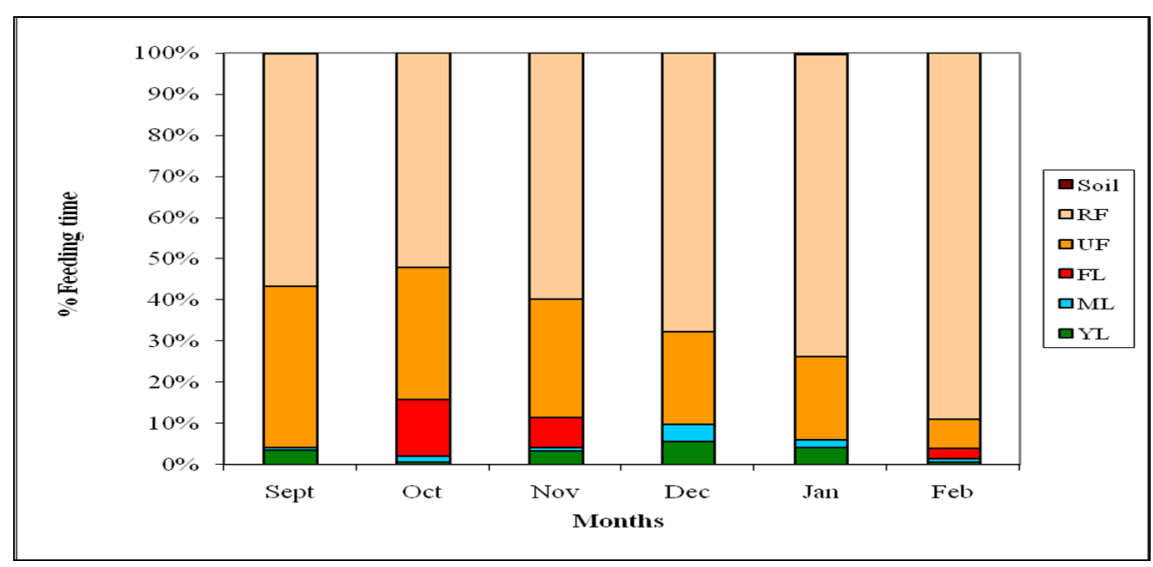

Figure 3. Monthly feeding time variation on different food types

$\mathrm{YL}=$ Young Leaves; $\mathrm{ML}=$ Mature Leaves; $\mathrm{FL}=$ Flowers; $\mathrm{UF}=$ Unripe Fruit and $\mathrm{RF}=$ Ripe Fruit.

\subsection{Plants Species Consumed}

E. coronatus consumed 45 plants species belonging to 27 families and 39 genera; these $60 \%$ were trees, $22 \%$ shrubs, $13 \%$ climbers, $2 \%$ herbaceous, and another $2 \%$ were epiphytes. Lemurs used the most Moraceae with 7 plant species; Lauraceae (5 plants species); Rosaceae and Rubiaceae ( 3 plants species). The crowned lemur spent $33 \%$ of feeding time on 7 species of Moraceae including 4 species of Ficus (F. albidula, F. barronii, F. botryoides, and F. Pyrifolia (Burm and Rosales)), Artocarpus heterophyllus, Pachytrophe dimepate and Streblus dimepate (Berg C.C. and Rosales). Lemur spent $13 \%$ on one species of Malvaceae (Grewia antsiranenesis) and $9 \%$ on 5 species of Lauraceae including Cryptocarya ambrensis, Ocotea bernieri, Persea amiricana, Raventsara crassifolia and Raventsara impressa (Laurales). Lemur spent also 7\% on one species of Maesaceae (Maesa acuminate)(DC and Ericales).

The lemurs ate more species of Ficus than plants of any other genus followed by Dracaena sp., Raventsara sp. and Solanum sp. of which lemurs consumed 2 species.

Of the 45 plants species consumed by lemur, 27 species were consumed for their fruits and seeds; 5 species for their leaves; 3 species for their fruits, seeds and flowers; also 3 species for their fruits; 2 species for their flowers; 2 species for their fruits and leaves; also 2 species for their fruits, seeds and leaves and one species for their fruits, seeds and flowers (Table 1). Table 1 lists the food plant species, time spent by lemurs on each part of each food plant (\%) and their habit.

Among the 45 food plant species used: $55.55 \%$ are endemic to Madagascar, $17.77 \%$ are cosmopolitan; $11.11 \%$ are naturalised in Madagascar; $4.44 \%$ are found only in Madagascar, the Union of the Comoros, the Mascarene Island and Africa; $2.22 \%$ are found only in Madagascar and the Union of the Comoros; $2.22 \%$ are found only in Madagascar, the Union of the Comoros and Africa; $2.22 \%$ are found in only Madagascar, the Union of the Comoros, Seychelles and Africa; $2.22 \%$ are found only in Madagascar and Africa; $2.22 \%$ are found only in Madagascar and Indonesia.

The number of plant species eaten varied from 3 to 13 species each day, but did not vary significantly across the days $(F=0.57, p=0.85)$. The number of plant species eaten each month ranged from 9 to 24 species, with the minimal number eaten in December and the maximal in October. The number of food plant species eaten varied significantly across the months $(F=4.47, p=0.02)$.

The number of food plant species used in dry (lately in dry season) and rainy (early in rainy season in this study) seasons were 33 and 28, respectively, and varied significantly across the seasons $(F=8.39, p=0.05)$.

For all plant species eaten, Eulemur coronatus ate Streblus dimepata and Maesa acuminate across all months of study. Trema orientalis, Passiflora ligularis, Pachytrophe dimepate, Lantana camara (L., Lamiales and Verbenaceae), F. pyrifolia and F. barronii were consumed for 4 months and other plant species were eaten less often (Table 2). 
Table 1. Food plants, food plant parts eaten and average feeding time (\%) on them

\begin{tabular}{|c|c|c|c|c|}
\hline Scientific Name & Family & $\begin{array}{l}\text { Average feeding } \\
\text { time (\%) }\end{array}$ & Part eaten & Habit \\
\hline Abies sp. & Pinaceae & 0.06 & YL & Tree \\
\hline Artocarpus heterophyllus Lam & Moraceae & 0.22 & $\mathrm{~F}, \mathrm{~S}$ & Tree \\
\hline Bakerella microcuspis (Baker)Tiegh. & Loranthaceae & 1.96 & YL,ML & Epiphyte \\
\hline Breonia decaryana Homolle & Rubiaceae & 0.11 & $\mathrm{~F}, \mathrm{~S}$ & Tree \\
\hline Canarium madagascariensis Engl & Burseraceae & 0.81 & $\mathrm{~F}, \mathrm{~S}$ & Tree \\
\hline Canthium medium Rich. & Rubiaceae & 3.12 & $\mathrm{~F}, \mathrm{~S}$ & Tree \\
\hline Cassipourea madagascariensis DC. & Rhizophoraceae & 0.06 & $\mathrm{~F}, \mathrm{~S}$ & Shrub \\
\hline Chrysophyllum boivinianum(Pierre) Baehni & Sapotaceae & 0.66 & $\mathrm{~F}, \mathrm{~S}$ & Tree \\
\hline Citrus madagascariensis & Rutaceae & 0.10 & $\mathrm{FL}, \mathrm{F}, \mathrm{S}$ & Shrub \\
\hline Coffeae perrieri Drake & Rubiaceae & 1.53 & $\mathrm{~F}, \mathrm{~S}$ & Tree \\
\hline Cryptocarya ambrensis & Lauraceae & 6.82 & $\mathrm{~F}, \mathrm{~S}$ & Tree \\
\hline Dichapetalum bojeri (Tul) Engl & Dichapetalaceae & 0.07 & $\mathrm{~F}, \mathrm{~S}$ & Climber \\
\hline Dracaena ensifolia (L.) DC & Asparagaceae & 0.84 & YL,F,S & Tree \\
\hline Dracaena gracilis Salisb. & Asparagaceae & 0.23 & YL, ML & Shrub \\
\hline Dypsis $S p$. & Arecaceae & 1.40 & $\mathrm{~F}, \mathrm{~S}$ & Tree \\
\hline Eriobotrya japonica Lindl & Rosaceae & 0.41 & $\mathrm{~F}, \mathrm{~S}$ & Shrub \\
\hline Eugenia lokohensis H. Perrier & Myrtaceae & 0.72 & $\mathrm{~F}, \mathrm{~S}$ & Tree \\
\hline Ficus albidula Baker & Moraceae & 0.30 & $\mathrm{~F}, \mathrm{~S}$ & Tree \\
\hline Ficus barronii Baker & Moraceae & 3.09 & $\mathrm{~F}, \mathrm{~S}$ & Tree \\
\hline Ficus botryoides Baker & Moraceae & 1.56 & $\mathrm{~F}, \mathrm{~S}$ & Tree \\
\hline Ficus pyrifolia Burm & Moraceae & 6.61 & F,S,YL & Shrub \\
\hline Grewia antsiranensis Capuron & Malvaceae & 13.36 & F,S & Shrub \\
\hline Harungana madagascariensis Lam.ex Poir & Hypericaceae & 2.21 & F,S & Tree \\
\hline Hypoestes angusta Benoist & Acanthaceae & 0.34 & YL,ML & Herbaceous \\
\hline Lantana camara $\mathrm{L}$. & Verbenaceae & 4.10 & $\mathrm{~F}, \mathrm{~S}$ & Shrub \\
\hline Maesa acuminata DC & Maesaceae & 7.47 & $\mathrm{~F}, \mathrm{~S}$ & Tree \\
\hline Medinilla ambrensis Jim and H. Perrier & Melastomataceae & 0.38 & F,S & Tree \\
\hline Mendoncia cowanii Benoist & Acanthaceae & 2.61 & $\mathrm{~F}, \mathrm{~S}, \mathrm{FL}$ & Climber \\
\hline Ocotea bernieri (Baill) Palacky & Lauraceae & 0.22 & YL,ML & Tree \\
\hline Olea ambrensis H. Perrier & Oleaceae & 0.19 & $\mathrm{~F}, \mathrm{YL}$ & Tree \\
\hline Pachytrophe dimepate Bureau & Moraceae & 0.91 & $\mathrm{~F}, \mathrm{~S}$ & Tree \\
\hline Passiflora ligularis Juss. & Passifloraceae & 1.22 & F,S,YL,ML & Climber \\
\hline Persea amiricana Mill & Lauraceae & 0.43 & $\mathrm{~F}$ & Tree \\
\hline Prunus persica (L.) Batsch & Rosaceae & 3.08 & $\mathrm{~F}$ & Tree \\
\hline Psorospermum chionathifolium & Hypericaceae & 0.16 & FL & Tree \\
\hline Raventsara crassifolia & Lauraceae & 0.51 & $\mathrm{~F}, \mathrm{~S}$ & Tree \\
\hline Raventsara impressa & Lauraceae & 0.76 & $\mathrm{~F}, \mathrm{~S}$ & Tree \\
\hline Rubus moluccanus L. & Rosaceae & 0.06 & $\mathrm{~F}$ & Climber \\
\hline Salacia madagascariensis (Lam) DC & Celastraceae & 3.31 & FL & Climber \\
\hline Smilax krussiana Meisn & Smilacaceae & 4.72 & F,S,YL & Climber \\
\hline Solanum aethiopicum $\mathrm{L}$. & Solanaceae & 1.22 & $\mathrm{~F}, \mathrm{~S}$ & Shrub \\
\hline Solanum betaceum Cav. & Solanaceae & 0.68 & $\mathrm{~F}, \mathrm{~S}$ & Shrub \\
\hline Streblus dimepate C.C. Berg & Moraceae & 20.52 & $\mathrm{~F}, \mathrm{YL}$ & Shrub \\
\hline Trema orientalis L.Blume & Ulmaceae & 0.75 & $\mathrm{~F}, \mathrm{~S}$ & Tree \\
\hline Uapaca ferruginea Baill & Phyllanthaceae & 0.10 & $\mathrm{~F}, \mathrm{~S}$ & Tree \\
\hline
\end{tabular}

$\mathrm{YL}=$ Young Leaves; $\mathrm{ML}=$ Mature Leaves; $\mathrm{FL}=$ Flowers; $\mathrm{F}=$ Fruit and $\mathrm{S}=$ Seed. 
Table 2. Monthly variation in feeding time (\%) on each plant species

\begin{tabular}{|c|c|c|c|c|c|c|}
\hline Scientific name & Sept & Oct & Nov & Dec & Jan & Feb \\
\hline Abies sp. & - & 0.33 & - & - & - & - \\
\hline Artocarpus heterophyllus & 0.57 & 0.33 & 0.40 & - & - & - \\
\hline Bakerella microcuspis & - & - & 1.21 & 9.81 & 0.75 & - \\
\hline Breonia decaryana & - & 0.66 & - & - & - & - \\
\hline Canarium madagascariensis & - & - & - & - & 4.87 & - \\
\hline Canthium medium & 10.09 & 8.25 & 0.40 & - & - & - \\
\hline Cassipourea madagascariensis & - & - & - & - & 0.37 & - \\
\hline Chrysophyllum boivinianum & 1.15 & - & 2.83 & - & - & - \\
\hline Citrus madagascariensis & 0.28 & 0.33 & - & - & - & - \\
\hline Coffeae perrieri & - & 2.31 & 6.88 & - & - & - \\
\hline Cryptocarya ambrensis & - & - & - & 22.90 & 13.48 & 4.55 \\
\hline Dichapetalum bojeri & - & - & 0.40 & - & - & - \\
\hline Dracaena ensifolia & - & - & - & - & 3.75 & 1.30 \\
\hline Dracaena gracilis & - & 0.66 & - & - & 0.75 & - \\
\hline Dypsis sp. & - & - & - & - & 4.49 & 3.90 \\
\hline Eriobotrya japonica & 0.58 & - & - & - & 1.87 & - \\
\hline Eugenia lokohensis & 4.32 & - & - & - & - & - \\
\hline Ficus albidula & - & 0.66 & - & - & 1.12 & - \\
\hline Ficus barronii & 1.73 & 10.56 & 4.86 & 1.40 & - & - \\
\hline Ficus botryoides & - & - & - & 9.35 & - & - \\
\hline Ficus pyrifolia & 2.59 & 20.13 & 16.19 & - & 0.75 & \\
\hline Grewia antsiranensis & - & - & - & - & 11.99 & 68.18 \\
\hline Harungana madagascariensis & 8.65 & 4.62 & - & - & - & - \\
\hline Hypoestes angusta & - & 0.33 & 1.21 & 0.47 & - & - \\
\hline Lantana camara & 13.83 & 4.62 & 4.86 & - & - & 1.30 \\
\hline Maesa acuminata & 14.41 & 3.63 & 4.45 & 3.27 & 16.48 & 2.60 \\
\hline Medinilla ambrensis & - & - & - & - & 2.25 & - \\
\hline Mendoncia cowanii & 5.76 & 6.27 & 3.64 & - & - & - \\
\hline Ocotea bernieri & - & - & - & - & - & 1.30 \\
\hline Olea ambrensis & 1.15 & - & - & - & - & - \\
\hline Pachytrophe dimepate & - & 0.99 & 2.83 & - & 0.37 & 1.30 \\
\hline Passiflora ligularis & 1.73 & 0.66 & - & - & 3 & 1.95 \\
\hline Persea amiricana & - & - & - & - & - & 2.60 \\
\hline Prunus persica & 3.75 & 1.98 & - & - & 12.73 & - \\
\hline Psorospermum chionathifolium & - & 0.33 & & & - & 0.65 \\
\hline Raventsara crassifolia & - & - & 1.21 & 1.87 & - & - \\
\hline Raventsara impressa & - & - & - & - & - & 4.55 \\
\hline Rubus moluccanus & - & 0.33 & - & - & - & - \\
\hline Salacia madagascariensis & - & 12.54 & 7.29 & - & - & - \\
\hline Smilax krussiana & 18.16 & 5.28 & 4.86 & - & - & - \\
\hline Solanum aethiopicum & 6.34 & 0.99 & - & - & - & - \\
\hline Solanum betaceum & - & - & & & 1.50 & 2.60 \\
\hline Streblus dimepate & 4.32 & 13.20 & 36.03 & 50 & 17.60 & 1.95 \\
\hline Trema orientalis & - & - & 0.40 & 0.93 & 1.87 & 1.30 \\
\hline Uapaca ferruginea & 0.58 & - & - & - & - & - \\
\hline
\end{tabular}




\subsection{Germination and the Latency Periods of Seeds}

The faecal samples contained flesh fruit parts, stalks, leaves, flowers, faecal liquid and seeds. Most seeds found in faecal samples were intact with minor scarification and represented 33 different species belonged to 23 families. Based on the collected sample, the most common large-sized seed species found in lemur defecations belonged to seven species; these were selected for more detailed analysis in this study (Table 3). For each of these seven species, seeds that had been defecated had a higher germination rate than non-passed seeds (Table 3). Passed and nonpassed seeds had a mean germination rate of $64.29 \%$ and $22.15 \%$, respectively. Lemur gut- passed seeds had significantly higher overall germination rates than non-passed seeds $(t=5.53, p=0.01)$. For each of these 7 species, the Pearson's Chi square test value was not statistically significant (Table 3).

The average latency period of passed and control seeds ranged from 40 to 87 days and from 47.5 to 91 days, respectively. The difference between these 2 averages ranged from 1.5 to 11 days (Table 4 ).

The Mann-Whitney test analysis was non-significant $(U=18, p=0.41)$ between the species but had different levels of significance across species (Table 4).

Table 3. List of species used to germination test

\begin{tabular}{llcccc}
\hline Scientific name & Family & \multicolumn{2}{c}{ Germination rate \% } & \multicolumn{2}{c}{ Pearson test } \\
\cline { 3 - 6 } & & 45 & 25 & 2.67 & .26 \\
\hline Canarium madagascariense & Burseraceae & 70 & 15 & 4.14 & .25 \\
Chrysophyllum boivinianum & Sapotaceae & 90 & 15 & 4.80 & .44 \\
Coffea perrieri & Rubiaceae & 60 & 40 & 3.81 & .43 \\
Cryptocarya ambrensis & Lauraceae & 75 & 25 & 5.11 & .16 \\
Dichapetalum bojeri & Dichapetalaceae & 60 & 15 & 3.87 & .42 \\
Eugenia lokohensis & Myrtaceae & 50 & 20 & 4.00 & .41 \\
Mendoncia cowanii & Acanthaceae & & & Chi-square & $P$-value \\
\hline
\end{tabular}

Table 4. Average latency period in days

\begin{tabular}{lccccc}
\hline Species & Passed seeds & Non-passed seeds & Differences & $U$ & \multicolumn{1}{l}{$P$} \\
\hline Canarium madagascariense & 40 & 47.5 & 7.5 & 8.5 & .14 \\
Chrysophyllum boivinianum & 77.5 & 81 & 3.5 & 4.00 & .48 \\
Coffea perrieri & 85.5 & 87 & 1.5 & 3.50 & .56 \\
Cryptocarya ambrensis & 47.5 & 55 & 7.5 & .50 & .02 \\
Dichapetalum bojeri & 64 & 75 & 11 & 9.00 & .11 \\
Eugenia lokohensis & 87 & 91 & 4 & 2.5 & .13 \\
Mendoncia cowanii & 84 & 87.5 & 3.5 & .50 & .08 \\
\hline
\end{tabular}

\section{Discussion}

E. coronatus spent the majority of their time for moving. More precisely, crowned lemurs devotes majority of their time moving and in the course of their movement visits more food sources (Dunn et al., 2009). However, crowned lemurs vast periods of their morning hours sleeping and commences with feeding activities in the noon during the period of moonlight. It is probably cathemeral behaviour that the animals exercise some nocturnal activity and take some rest in the morning. The feeding time varied across the months. Seasons may affect lemur's activity by photoperiod and nocturnal ambient luminosity (Donati et al., 2006).

E. coronatus consumed the variety of food types. The high percentage of feeding time eating fruit of $E$. coronatus confirms a primarily frugivorous habit for the species (Freed, 1996; Sussman, 2002).

The consumption of ripe fruit varied significantly across months. Feeding times on ripe fruit increase from September to February while feeding times on unripe fruit decrease across the season. During the period of resources scarcity most of frugivores animals consumed unripe fruits (Schaeffer \& Schmidt, 2002). According to 
Nelson et al. (2000), in the same fruit species both unripe and ripe fruits provided the same levels of nutrients for many organic and mineral components. But consumption of unripe fruits is considered as a low quality dietary because of their less valuable nutritional contents and their important value of deterrent secondary metabolites (Schaeffer \& Schmidt, 2002). Also in same species, unripe fruit had high levels of calcium than ripe fruit but it was only half contain in iron than ripe fruit (Nelson et al., 2000).

The leaves are being taken only rarely. According to Dunn et al. (2010) frugivorous animals consumed leaves when they want to diversify their food source for obtaining the best complement of nutrients and for avoiding an overload of particular toxins. Curtis (2004) emphasized that the young leaves have a high percentage of crude protein and essential amino acids; they are consumed probably because of their abilities to satisfy the requirement of essential nutrients and protein (Kumar \& Solanki, 2004). Leaves can also stabilize the foregut environment for digestion (Solanki et al., 2008).

The flowers constituted 14\% of crowned lemur's diet and the highest value is in October. Curtis (2004) through his work on wild diet on Mongoose lemurs in north western of Madagascar revealed that most of animals consumed flowers because of their high composition on water soluble carbohydrates and energy. Eating flowers are necessary to complete their diet and satisfy their body need in energy. They are mostly used during dry season.

Crowned lemurs spent around $0.13 \%$ of their total feeding time eating soil. This type of soil was consumed in September and January. Many authors reported that soil consumption by lemurs (geophagy) help them with digestion, add certain nutrients to their diet that they do not get from their normal food and help them too to soak up toxins form plant food. The soil is consumed for its mineral content (Ganzhorn, 1987). E. coronatus drink water using hands from the trees holes.

Forty five food plant species provided a spectrum diet for E. coronatus in the complex of Amber Mountain National Park. Schwitzer et al. (2006) reported nearly equal numbers of plants species in the diets of Eulemur macaco flavifrons (Gray, Primates and Lemuridae).

The plant species consumed belong to 27 families distributed in 39 genera. Wright et al. (2011) recorded almost the same numbers of plant food families and genera in the diet of Eulemur rubiventer (Geoffroy, Primates and Lemuridae) and Eulemur fulvus rufus (Audebert, Primates and Lemuridae).

Crowned lemurs spent more than $33 \%$ of their feeding time eaten Moraceae plant family. Species of Moraceae family are rich in tannins (Kendrick et al., 2009). Food items rich in tannins can minimize the possibility of iron absorption (Krishnamani \& Mahaney, 2000). As frugivorous, fruits are important in crowned lemur's diet. Fruit is a primary source of vitamin $\mathrm{C}$ and rich in iron. Lemur can also provide their own vitamin $\mathrm{C}$ (Nakajima et al., 1969). For the lemurs, the high rate in vitamin $C$ can be responsible of iron overload disorder because the vitamin $\mathrm{C}$ increase iron absorption.

Ficus genera is the most used genera in Eulemur coronatus' diet. According to Shanahan et al. (2001) and Dunn et al. (2010) fig trees can be consider as an important source of fruit during all periods however they have been accounted among those fallback food during periods of fruit scarcity.

The number of food plant species was very significant across the months and across the season. The variation of number of food plants species consumed in diet may depends on food availability, feeding time and others types of observations. The number of food plant species consumed and the time spent during feeding were low in December than others months and also in the beginning of rainy season than the end of dry season probably due to the season and the bad weather which often accompanied by very heavy rains. Crowned lemurs spent more time for rest in December more than other months in this study. Temperature may be associated with daytime activity (Donati et al., 2006). Lemurs reduce their physical efforts, they move only to reach food sources and spent more time for rest to conserve energy (Dunn et al., 2010).

Passed seed germinated better than control seeds that indicating the positive effects of the lemur species on plant species they consumed (Stevenson et al., 2002). Passed seeds had shorter latency period than control seeds showing that the passage of seeds in E. coronatus's gut improved the germination of plant species (Razafindratsima \& Razafimahatratra, 2010; Chapman \& Chapman, 1996; Poulsen et al., 2001). These findings showed that the gutpassage of seeds activate the chemical scarification for better germination rate (Mc key, 1975; Dew \& Wright, 1998; Razafindratsima \& Razafimahatratra, 2010). It can be considerate as a strategy of the plants species to reduce their time spending in embryogenesis phase to avoid the seed predators (Dew \& Wright, 1998; Wehncke \& Dalling, 2005; Razafindratsima \& Razafimahatratra, 2010). 
E. coronatus is seed vector; it can play an important role in plant species regeneration and especially in forest diversity maintenance. E. coronatus's role in forest is very important for endemic plant species, which constitute more than $50 \%$ of their diet.

During the preliminary study in field, it was very difficult to find a group of crowned lemur. According to the peasant and the guides, the number of crowned lemur's population decrease the last 5 years and it is almost rare to find a crowned group in the forest. It will be necessary to redefined quickly the conservation strategy of crowned lemur especially in Amber forest.

\section{Conclusion}

This study provides information on the role of E. coronatus in the Amber forest ecosystem through the spectrum of their diet and in germination test on their gut-passed seeds. E. coronatus's diet reveals that they are highly frugivorous and they favored mostly the plant species of Moraceae family maybe for their high composition on tannins to prevent disease and for their availability as fallback food. Like many primate species, E. coronatus's gut improved the germination rate of seeds and reduced their latency period. E. coronatus's can be considerate as seed disperser in Amber forest. This species can be beneficial to Madagascar endemic plant species. Through this study, we can conclude that the lemur's daily life depends on Amber forest and the forest need the lemur for their natural regeneration. Thus, this study showed the beneficial inter-dependence relation between this species and the Amber forest. To improve the strategy of conservation in Amber Mountain National Park, It will be recommended to protect not only the lemurs but also the plant species they used as food.

\section{Acknowledgements}

Authors' great full acknowledge Chinese and Malagasy Scholarship Council; the Department of Water and Forest (DEF), CAFF/ CORE Members, Ecole Supérieur des Sciences Agronomiques d'Antananarivo (ESSA) and Madagascar National Park Office (MNP) for their unconditional support.

\section{References}

Altmann, J. (1974). Observational study of behaviour: sampling methods. Behavior, 49, 227-265. http://dx.doi.org/ $10.1163 / 156853974$ X00534

Angap. (1998). Ministère de l'Environnement, des eaux et Forets, 1998: Plan de gestion du Réseau National des Aires Protégées de Madagascar, Antananarivo Madagascar.

Chapman, C. A., \& Chapman, L. J. (1996). Frugivory and the fate of dispersed and non-dispersed seeds of six African tree species. Journal of Tropical Ecology, 12(4), 491-504. http://dx.doi.org/10.1017/S026646740000 $972 X$

Curtis, D. J. (2004). Diet and nutrition in wild mongoose lemurs (Eulemur mongoz) and their implications for the evolution of female dominance and small group size in lemurs. Journal of Physical Anthropology, 124(3), 234-247. http://dx.doi.org/10.1002/ajpa.10268

Dew, J. L., \& Wright, P. (1998). Frugivory and seed dispersal by four species of primates in Madagascar's eastern rain forest. Biotropica, 30, 425-437. http://dx.doi.org/10.1111/j.1744-7429.1998.tb00076.x

Donati, G., \& Borgognini-Tarli, S. M. (2006). Influence of abiotic factors on cathemeral activity: the case of Eulemur fulvus collaris in the littoral forest of Madagascar. Folia Primatologica, 77, 104-122. http://dx.doi.org/10.1159/000089698

Dunn, J. C., Cristobal-Azkarate, J., \& Vea, J. J. (2009). Differences in diet and activity pattern between two groups of Alouatta palliata associated with the availability of big trees and fruit of top food taxa. American Journal of Primatology, 71, 654-662. http://dx.doi.org/10.1002/ajp.20700

Dunn, J. C., Cristobal-Azkarate, J., \& Vea, J. J. (2010). Seasonal variations in the diet and feeling effort of two groups of howlers in different sized forest fragements. International Journal of Primatology, 31, 887-903. http://dx.doi.org/10.1007/s10764-010-9436-0

Freed, B. Z. (1996). Co-occurrence among crowned lemurs (Lemur coronatus) and Sanford's (Lemur fulvus sanfordi) of Madagascar ( Ph.D. Thesis). Washington University, St. Louis. USA.

Ganzhorn, J. U. (1987). Soil consumption of two groups of semi-free-ranging Lemurs (lemur catta and Lemur fulvus). Ethology, 74(2), 146-154. http://dx.doi.org/10.1111/j.1439-0310.1987.tb00927.x

Gupta, A. K., \& Kumar, A. (1994). Feeding ecology and conservation of the Phayre's leaf monkey Presbytis phayrei in northeast India. Biological Conservation, 69, 301-306. http://dx.doi.org/10.1016/0006-3207(94) 90430-8 
Humbert, H., \& Cours Darne, G. (1965). Carte internationale du tapis végétal et des conditions écologiques. $N^{0} 10$ Baie d'Ampasindava. CNRS et O.R.S.T.O.M. 1965. Toulouse, France.

Kendrick, E. L., Shipey, L. A., Hagerman, A. E., \& Kelley, L. M. (2009). Fruit and fibre: the nutritional value of figs for a small tropical ruminant, the blue duiker (Cephalophus monticola). African Journal of Ecology, 47, 556-566. http://dx.doi.org/10.1111/j.1365-2028.2008.00985.x

Kumar, A., \& Solanki, G. S. (2004). A rare feeding observation on water lilies (Nymphaea alba) by the capper langur, Trachypithecus pileatus. Folia Primatologica, 75, 157-159. http://dx.doi.org/10.1159/000078306

Krishnamani, R., \& Mahaney, W. C. (2000). Geophagy among primates: adaptive significance and ecological consequences. Animal Behaviour, 59(5), 899-915. http://dx.doi.org/10.1006/anbe.1999.1376

Mc Key, D. (1975). The ecology of coevolved seed dispersal systems. In L. E. Gilbert, \& P. Raven (Eds.), Coevolution of animals and plants: Symposium V, First International Congress of Systematic and Evolutionary Biology (pp. 159-191). Boulder, Colorado.

Mittermeier, R. A., Hawkins, F., Rajaobelina, S., \& Langrand, O. (2005). Wilderness conservation in biodiversity hotspot. International Journal Wilderness, 11(3), 42-45.

Mittermeier, R. A., Louis, JR. E. E., Langrand, O., Schwitzer C., Gauthier, C. A., Rylands, A. B., ... Kappeler, P. M. (2014). Lemuriens de Madagascar. Conservation International.

Nakajima, Y., Shantha, T. R., \& Boume, G. H. (1969). Histochemical detection of L-gulonolactone: phenazine methosulfate oxidoreductase activity in several mammals with special reference to synthesis of vitamin $\mathrm{C}$ in primates. Histochemie, 18(4), 293-301.

Nelson, S. L., Miler, M. A., Heske, E. J., \& Fahey, G. C. Jr. (2000). Nutritional quality of leaves and unripe fruit consumed as famine foods by the flying foxes of Samoa. Pacific Science, 54(4), 301-311.

Poulsen, J. R., Clark, C. J., \& Smith, T. B. (2001). Seed dispersal by a diurnal primate community in the Dja Reserve, Cameroon. Journal of Tropical Ecology, 17, 787-808. http://dx.doi.org/10.1017/S0266467401 001602

Rakotoarimanana, J., \& Edmond, J. R. (1990). Typologie des formations végétales du parc de la Montagne d'Ambre. Projet de recherche de l'écologie végétale, Faculté des Sciences, Université d'Antananarivo, Madagascar.

Razafindratsima, O. H., \& Razafimahatratra, E. (2010). Effect of red ruffed lemur gut passage on the germination of native rainforest plant species. Lemur News, 15, 39-41.

Razafindratsima, O. H., \& Martinez, B. T. (2012) Seed dispersal by red- ruffed lemurs: seed size, viability, and beneficial effect on seedling growth. Ecotropica, 18, 15-26.

Rossi, G., \& Rossi, M. (1998). La montagne d'Ambre (extrême nord de Madagascar) espace a proteger Cahiers d'analyse spatiale quantitative et appliquée. N0 38-39, Université de Nice, France.

Schaefer, H. M., \& Schmidt, V. (2002). Feeding strategies and food intake of blackscapes (Sylvia atricapilla) consuming ripe or unripe fruits and insects. Journal of Ornithology, 143, 341-350. http://dx.doi.org/10.1007/ BF02465484

Schwitzer, C., Schwitzer, N., Randriatina, G. H., Rabarivola, C., \& Kaumanns, W. (2006). "Programme Sahamalaza". New perspectives for the in situ and ex situ astudy and conservation of the blue-eyed black lemur (Eulemur macaco flavifrons) in a fragmented habitat. Proceedings of the German-Malagay Research Cooperation in Life and Earth Sciences, Concept Verlag, Berlin.

Shanahan, M., So, S., Compton, S. G., \& Corlett, R. (2001). Fig eating by vertebrate frugivores: a global review. Biological Reviews, 76, 529-572. http://dx.doi.org/10.1017/S1464793101005760

Smith, R. L., \& Smith, T. M. (2000). Elements of ecology. San Francisco: Benjamin/Cummings. http://dx.doi.org/ $10.2307 / 177462$

Solanki, G. S., Kumar, A., \& Sharma, K. B. (2008). Feeding ecology of Trachypithecus pileatus in India. International Journal of Primatology, 29, 173-182. http://dx.doi.org/10.1007/s10764-008-9234-0

Stevenson, P. R. (2000). Seed dispersal by woolly monkeys (Lagothrix lagothricha) at Tinigua National Park, Colombia: dispersal distance, germination rates, and dispersal quantity. American Journal of Primatology, 50, 275-289. http://dx.doi.org/10.1002/(SICI)1098-2345(200004)50:4<275::AID-AJP4>3.3.CO;2-B 
Stevenson, P. R., Castellanos, M. C., Pizarro, J. C., \& Garavito, M. (2002) Effects of seed dispersal by three ateline monkey species on seed germination at Tinigua National Park, Colombia. International Journal of Primatology, 23(6), 1187-1204. http://dx.doi.org/10.1023/A:1021118618936

Sussman, R. W. (2002). Adaptive array of lemurs of Madagascar revisited. Evolutionary Anthropology, 11, 75-78. http://dx.doi.org/10.1002/evan.10062

Terranova, C. J., \& Coffman, B. S. (1997). Body weights of wild and captive lemurs. Zoo Biology, 16, 17-30. http://dx.doi.org/10.1002/(SICI)1098-2361(1997)16:1<17::AID-ZOO4>3.3.CO;2-J

Traveset, A., \& Verdu, M. (2002). A meta-analysis of the effect of gut treatment on seed germination. In: Levey DJ, Sila WR, Galetti M (eds.). Seed dispersal and frugivory: ecology, evolution and conservation, CAB International, UK. http://dx.doi.org/10.1079/9780851995250.0339

Trigui S.M. (2010). Etude floristique et biogeographique des altitudes supérieures de la montagne d'Ambre (Nord de Madagascar) (Master thesis). Université de Genève, Suisse.

Wehncke, E. V., \& Dalling, J. W. (2005). Post-dispersal seed removal and germination-selected tree species dispersed by Cebus capucinus on Barro Colorado Island, Panama. Biotropica, 37, 73-80. http://dx.doi.org/10. 1111/j.1744-7429.2005.03037.x

Wilson, J. M. (1989). Ecology and conservation of the Crowed lemur at Ankarana, Madagascar. Folia Primatologica, 52, 1- 26. http://dx.doi.org/10.1159/000156379

Wright, P. C., Tecot, S. R., Erhart, E. M., Baden, A. L., King, S. J., \& Grassi, C. (2011). Frugivory in four sympatric lemurs: implications for the future of Madagascar's forests. American Journal of Primatology, 73, 585-602. http://dx.doi.org/10.1002/ajp.20936

\section{Copyrights}

Copyright for this article is retained by the author(s), with first publication rights granted to the journal.

This is an open-access article distributed under the terms and conditions of the Creative Commons Attribution license (http://creativecommons.org/licenses/by/3.0/). 